\title{
Pengaruh Pembelajaran Matematika Dengan Berbantuan Media Animasi Kartun Dan Motivasi Belajar Terhadap Kemampuan Pemahaman Matematik Siswa Kelas 5 Sekolah Dasar
}

\author{
Ervin Yunia Dwi Antari ${ }^{1}$, Supriadi ${ }^{2}$, Sandra Sukmaning Adji ${ }^{3}$ \\ ${ }^{1}$ Universitas Terbuka, Indonesia \\ ${ }^{2}$ Universitas Pendidikan Indonesia, Indonesia \\ ${ }^{3}$ Universitas Terbuka, Indonesia \\ Email : ervinyuniadwiantari@gmail.com, supriadi.upiserang@upi.edu, \\ sandra@ecampus.ut.ac.id
}

\begin{abstract}
ABSTRAK
Penelitian ini bertujuan untuk mengetahui pengaruh pembelajaran matematika dengan berbantuan media animasi kartun dan motivasi belajar terhadap pemahaman matematik peserta didik.Metode penelitian yang digunakan dalam penelitian ini adalah Quasi experimental design dengan rancangan factorial 2 x 3, penelitian dilaksannakan di sekolah dasar negeri di kecamatan Pulomerak dengan sampel siswa kelas V pada dua sekolah dasar. Pengambilan sampel menggunakan Teknik Convinan Sampling. Teknik sampling ini dilakukan dengan cara mensepadankan antara satu subjek dengan subjek yang lain berdasarkan nilai pretest maupun IQ, yakni dengan cara menranking semua subjek dari tertinggi sampai terendah.Populasi dalam penelitian adalah seluruh siswa sekolah dasar pada gugus 2 kecamatan Pulomerak yang berjumlah 8 sekolah dasar negeri dengan jumlah siswa 274. Dalam penelitian ini terdapat tiga variable penelitian yaitu 2 variabel bebas dan satu variable terikat. Variabel bebas adalah media animasi kartun dan motivasi belajar sedangkan variable terikat adalah pemahaman matematik siswa. Penelitian dimulai dengan pemberian pretest untuk mengukur kemampuan siswa dan angket motivasi untuk mengklasifikasi tingkat motivasi belajar siswa, selanjutnya siswa diberikan treatment sebanyak delapan kali pertemuan pada kelas eksperimen dengan berbantuan media anmiasi kartun sedangkan pada kelas kontrol tidak diberi treatment hanya menggunakan media gambar, dan pada pertemuan terakhir diberi soal posttest untuk dianalisis. Data dalam peneltian ini diperoleh dari hasil posttest kemampuan pemahaman matematik dan angket mortivasi siswa. Pengolahan data dilakukan dengan menggunakan perhitungan anava dua jalur dilanjutkan dengan uji lanjutan yaitu uji Teknik Tuckey. Berdasarkan hasil analisis data yang telah terkumpul melalui instrumen penelitian diperoleh kesimpulan dari hasil pengolahan data yaitu pertama, kemampuan pemahaman matematik pada kelas ekperimen menggunakan media amimasi kartun lebih unggul dari pada kelas kontrol yang menggunakan media gambar; kedua, lebih unggul kemampuan pemahaman matematik berdasarkan motivasi belajar siswa; ketiga, terdapat pengaruh interaksi antara pembelajaran dengan berbantuan animasi dan motivasi belajar terhadap kemampuan pemahaman matematik.
\end{abstract}

Kata kunci : media animasi kartun, motivasi belajar, pemahaman matematik

\section{ABSTRACT}

This study aims to determine the effect of learning mathematics with the aid of cartoon animation media and learning motivation on students' mathematical understanding. The research method used in this study was a quasi experimental design with a $2 \times 3$ factorial design, the research was carried out in a public elementary school in Pulomerak sub-district with sample of fifth grade students in two elementary schools. Sampling using Convinan 
Sampling Technique. This sampling technique is done by matching one subject with another subject based on pretest and IQ scores, namely by ranking all subjects from the highest to the lowest. The population in the study were all elementary school students in cluster 2, Pulomerak sub-district, which amounted to 8 public elementary schools. with the number of students 274. In this study there are three research variables, namely 2 independent variables and one dependent variable. The independent variable is cartoon animation media and learning motivation, while the dependent variable is students' mathematical understanding. The study began by giving a pretest to measure students' abilities and a motivational questionnaire to classify the level of student learning motivation, then students were given treatment for eight meetings in the experimental class with the help of cartoon animation media while the control class was not given treatment using only picture media, and at the meeting Finally, they were given posttest questions to be analyzed. The data in this study were obtained from the posttest results of students' mathematical understanding abilities and student motivation questionnaires. Data processing was carried out using two-way ANOVA calculations followed by a further test, namely the Tuckey Technique test. Based on the results of data analysis that has been collected through research instruments, conclusions are obtained from the results of data processing, namely first, the ability to understand mathematics in the experimental class using cartoon animation media is superior to the control class using image media; second, there are differences in the ability to understand mathematics based on students' learning motivation; third, there is an interaction effect between animation-assisted learning and learning motivation on the ability to understand mathematics.

Keywords: cartoon animation media, learning motivation, mathematical understanding

\section{PENDAHULUAN}

Pendidikan merupakan kebutuhan manusia yang primer, kebutuhan yang harus dipenuhi untuk masa depan, tujuannya untuk bertahan hidup dalam mencukupi kebutuhan untuk mencari pangan, sandang dan tempat tinggal, dengan pendidikan manusia memperoleh ilmu pengetahuan, nilai sikap dan keterampilan untuk bersaing dan dapat mengikuti perkembangan jaman yang modern seperti sekarang ini. Pendidikan tidak terlepas dari kegiatan belajar mengajar, sebab tanpa belajar manusia mungkin tidak dapat mengembangkan bakat, motivasi, dan kepribadiannya sesuai dengan kemampuan yang dimiliki oleh siswa. Salah satu tahapan pendidikan yang penting dan dapat menciptakan generasi muda yang berkualitas adalah di sekolah. Tempat ini adalah ujung tombak dari pembentukan karakter generasi muda. Pembelajaran di sekolah dasar mata pelajaran diajarkan secara tematik atau memuat beberapa mata pelajaran yang dipadukan, dan salah satu mata pelajaran yang berdiri sendiri tanpa dipadukan untuk kelas tinggi adalah matematika, dalam mata pelajaran matematika di ajarkan konsep dan rumus-rumus yang berhubungan dengan kegiatan kehidupan sehari-hari di masyarakat.

Karakteristik matematika merupakan konsep-konsep yang berkaitan erat dan berguna dalam kehidupan sehari-hari. Konsep-konsep matematika tersebut haruslah dikuasai dengan baik, sehingga ketika siswa menemukan permasalahan yang serupa dengan konsep tersebut maka siswa dapat menyelesaikan permasalahan yang ada. Pemahaman konsep matematika yaitu kemampuan siswa dalam memahami konsep matematika, baik secara teori maupun dalam penerapannya di kehidupan sehari-hari.

Kamarullah (2017) menekankan bahwa siswa dituntut sesuai kurikulum dengan tujuan yang lebih luas, yakni : (1) memahami konsep matematika, menjelaskan keterkaitan antarkonsep dan menerapkan konsep atau algoritma, secara fleksibel, cermat, efisien, dan tepat, 
dalam menyelesaikan masalah; (2) menggunakan penalaran pada pola dan sifat, melakukan manipulasi matematika dalam membuat generalisasi, menyusun bukti, atau menjelaskan gagasan dan pernyataan matematika; (3) menyelesaikan masalah yang meliputi kemampuan memahami masalah, merancang model matematika, menyelesaikan model dan menyimpulkan solusi yang diperoleh; (4) menyampaikan gagasan dengan simbol, tabel, diagram, atau media lain untuk memperjelas keadaan atau masalah; (5) memiliki sikap menghargai kegunaan matematika dalam kehidupan, yaitu memiliki rasa ingin tahu, perhatian, dan motivasi dalam mempelajari matematika, serta sikap gigih dan percaya diri dalam pemecahan masalah.

Pada kenyataannya pelajaran matematika adalah mata pelajaran yang selama ini dianggap sulit oleh sebagian besar siswa, mulai dari jenjang sekolah dasar sampai sekolah menengah. Kesulitan yang dialami oleh siswa dalam menguasai konsep-konsep matematika disebabkan karena banyak materi matematika yang berkaitan dengan berhitung dan dalam menerapkan rumus-rumus dalam menyelesaikan soal-soal serta dalam mengaplikasikan konsep matematika dalam kehidupan sehari-hari dianggap sulit oleh siswa.

Keberhasilan proses pembelajaran matematika itu sendiri dipengaruhi oleh beberapa komponen yaitu salah satu komponen yang penting dalam penyampaian materi ajar kepada siswa adalah dengan penggunaan media pembelajaran. Penggunaan media pembelajaran akan sangat membantu ketika guru merasa kesulitan dalam menjelaskan materi pelajaran tertentu yang kurang maksimal apabila hanya dijelaskan oleh kata-kata. Namun guru kurang memperhatikan hal tersebut, karena dianggap menambah pekerjaan terutama dengan menentukan media pembelajaran yang cocok dan mendukung terhadap proses pembelajaran yang dilaksanakan.

Berdasarkan data dari Trend In International Mathematics And Science Study (TIMSS) yang dilakukan secara rutin setiap 4 tahun sekali, yaitu tahun 1995, 1999, 2003, 2007, 2011 dan 2015. Indonesia termasuk salah satu negara yang menjadi objek TIMSS pada empat periode terakhir. Terkait prestasi matematika, posisi Indonesia masih dibawah internasional seperti yang dilansir oleh TIMSS. Hasil studi TIMSS 2003, Indonesia berada di peringkat 35 dari 46 negara peserta dengan skor rata-rata 411, sedangkan rata-rata skor internasional 467. Hasil studi TIMSS 2007, Indonesia berada di peringkat 36 dari 49 negara peserta dengan skor rata-rata 397, hasil studi TIMSS 2011, Indonesia berada diperingkat 38 dari 42 negara peserta dengan skor rata-rata 386, sedangkan skor rata-rata internasional 500 (P4TK, 2011). Dan hasil terbaru, yaitu TIMSS 2015 Indonesia berada di peringkat 44 dari 49 negara (Nizam, 2016) 
Tabel 1. Hasil TIMSS Indonesia

\begin{tabular}{|c|c|c|c|c|}
\hline \multicolumn{5}{|c|}{ Hasil TIMSS } \\
\hline Tahun & Peringkat & Peserta & $\begin{array}{c}\text { Rata-rata skor } \\
\text { Indonesia }\end{array}$ & $\begin{array}{l}\text { Rata-rata skor } \\
\text { Internasional }\end{array}$ \\
\hline 2003 & 35 & 46 & 411 & 467 \\
\hline 2007 & 36 & 49 & 397 & 500 \\
\hline 2011 & 38 & 42 & 386 & 500 \\
\hline 2015 & 44 & 49 & 397 & 500 \\
\hline
\end{tabular}

Dengan kriteria TIMSS membagi pencapaian peserta survei ke dalam empat tingkat: rendah (low 400), sedang (intermediate 475), tinggi (high 550) dan lanjut (advanced 625) dari data di atas sehingga posisi Indonesia berada pada tingkat rendah.(Hadi dan Novaliyosi, 2019). Berdasarkan data diatas dapat disimpulkan bahwa hasil survey TIMSS Indonesia mendapat peringkat rendah, karena rata- rata skor yang didapatkan 400 dan masuk dalam kategori low, ini menandakan dalam kemampuan pemahaman konsep matematika masih terbilang rendah dan perlu dilakukan perbaikan dalam pembelajarannya.

Supriadi (2016) menyatakan bahwa pembelajaran matematika yang dilaksanakan oleh guru dan siswa harus kreatif, inovatif, dan tekun dalam proses pembelajarannya. Peneliti merasa bahwa pembelajaran matematika yang selama ini dilakukan kurang kreatif, inovatif dan dalam pembelajarannya siswa tidak tekun mengikuti. Dari permasalahan yang ada peneliti berupaya untuk melaksanakan pembelajaran yang kreatif, inovatif dan dapat menjadikan siswa untuk tekun dalam pembelajaran matematika yaitu dengan menggunakan media yang menarik.

Selain permasalahan di atas ternyata motivasi siswa rendah dalam mengikuti proses pembelajaran matematika yang dilaksanakan via zoom, dari permasalahan itu maka peneliti beranggapan bahwa jika kita memaksakan siswa untuk mengikuti pembelajaran yang dilaksanakan dengan cara yang konvensional maka pembelajaran di anggap tidak akan berhasil dan tujuan dari pembelajaran tidak akan tercapai. Dari permasalahan tersebut maka diperlukan media yang dapat meningkatkan motivasi belajar dan dapat membantu kemampuan pemahaman konsep matematika siswa kelas 5 sekolah dasar.

Dari permasalahan di atas perlu diteliti tentang penggunaan media yang di anggap menarik, media itu adalah media animasi kartun. Gambar yang bergerak berasal dari kumpulan berbagai benda yang diatur secara khusus sehingga bergerak sesuai dengan jalan yang telah ditentukan pada setiap hitungan waktu inilah yang disebut animasi kartun. Objek yang dimaksud adalah gambar manusia, gambar binatang, tulisan teks, gambar tumbuhan, bangunan, dan sebagainya.

Zakirman \& Hidayati (2017), memberi penjelasan bahwa media animasi adalah salah satu bahan ajar audio-visual yang dapat diaplikasikan dalam kegiatan pembelajaran. Bahan ajar audio-visual adalah bahan ajar yang menggabungkan kemampuan audio dan dilengkapi sajian berupa gambar bergerak atau visual.

Hasanah \& Nulhakim (2015), memberikan pengertian bahwa penggunaan media film animasi dalam pembelajaran memberikan suasana yang baru dan menyenangkan bagi perserta didik dapat meningkatkan minat dan motivasi siswa dalam belajar. Penggunaan media film animasi dalam proses pembelajaran dapat meningkatkan kualitas proses dan hasil belajar, karena film animasi bersifat menarik. Apabila media film animasi ini sudah menarik perhatian siswa, maka diharapkan informasi akan lebih mudah dimengerti, karena untuk menyerap informasi yang diberikan menggunakan dua indera yang terlibat yaitu telinga dan mata. 
Dalam pembelajaran matematika yang terpenting adalah bagaimana guru dapat memberikan pembelajaran yang dapat membantu siswa untuk memahami konsep matematika, karena pada mata pelajaran matematika terdapat banyak konsep yang sulit untuk dipahami dan dimengerti dan banyak materi yang susah untuk diterapkan dalam kehidupan sehari-hari sehingga butuh alat bantu dalam proses pembelajarannya salah satunya adalah media pembelajaran yang menarik yang dapat menarik perhatian dan memotivasi siswa, media pembelajaran tersebut adalah video pembelajaran animasi kartun. Yang dianggap menarik dan dapat meningkatkan motivasi siswa serta dapat membantu siswa dalam memahami konsepkonsep matematika.

\section{METODE}

Metode penelitian yang digunakan dalam penelitian ini adalah metode penelitian eksperimen quasi. Eksperimen ini disebut juga eksperimen semu karena penelitian quasi eksperimen langsung mengambil dua kelas sampel secara langsung yang sudah terbentuk dalam kelompok yang utuh. Salah satu kelas diberi treatment dan kelas yang lain dijadikan pembanding.(Zainal Arifin, 2013)

Fraenkel, Jack R \& Norman E. Wallen (2009) Desain penelitian yang digunakan adalah The Matching-Only Posttest Control Group Design. Desain penelitian ini terdiri atas dua kelompok yaitu kelompok eksperimen (ada perlakuan) dan kelompok kontrol (tidak ada perlakuan). Subyek penelitian dilakukan satu kali test yaitu teks akhir (posttest) yang disajikan seperti pada desain berikut :

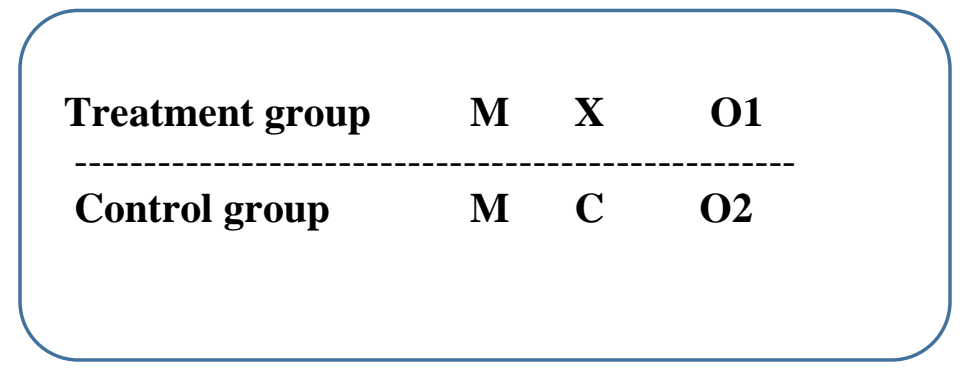

Keterangan :

M : Macthing sampel (pemasangan sampel)

$\mathrm{X}$ : Treatment menggunakan media animasi kartun

$\mathrm{C}$ : Pembelajaran tanpa media media animasi kartun

$\mathrm{O} 1$ : Pemberian tes yang diajar menggunakan media animasi kartun

$\mathrm{O} 2$ : Pemberian tes yang diajar tanpa menggunakan media animasi kartun

Desain kuasi eksperimen yang digunakan dalam penelitian ini adalah desain kelompok control non-ekuivalen.Dalam desain ini, baik kelompok eksperimen maupun kelompok control tidak dipilih secara acak. Dalam desain ini kelas eksperimen dan kelas kontrol mendapatkan uji satu kali, yaitu post-test. Kedua kelas ini dalam proses pembelajaran mendapatkan perlakuan yang sama dari segi tujuan dan isi materi pelajaran. Perbedaan diantara kedua kelas tersebut adalah digunakannya media animasi kartun untuk mencipkan motivasi pada pembelajaran sedangkan pembelajaran pada kelas kontrol dengan menggunakan pembelajaran konvensional dengan bantuan media gambar.

\section{HASIL DAN PEMBAHASAN}


Uji-t dilakukan untuk menguji signifikasi hasil penelitian yang berupa perbandingan keadaan variabel dari dua rata-rata antara kelas yang diajar dengan menggunakan media animasi kartun pada siswa yang memiliki motivasi tinggi, sedang dan rendah. Syarat pengambilan keputusan uji hipotesis yaitu apabila nilai signifikasi lebih kecil dari 0.05 maka dinyatakan terdapat perbedaan yang signifikan. Perhitungan dilakukan dengan menggunakan bantuan SPSS versi 25.0

1. Lebih unggul kemampuan pemahaman matematik siswa yang belajar dengan media animasi kartun pada siswa yang memiliki motivasi tinggi dengan siswa yang belajar dengan media gambar yang memiliki motivasi tinggi.

Tabel 2. Rangkuman hasil Uji-t A1B1 dan A2B1

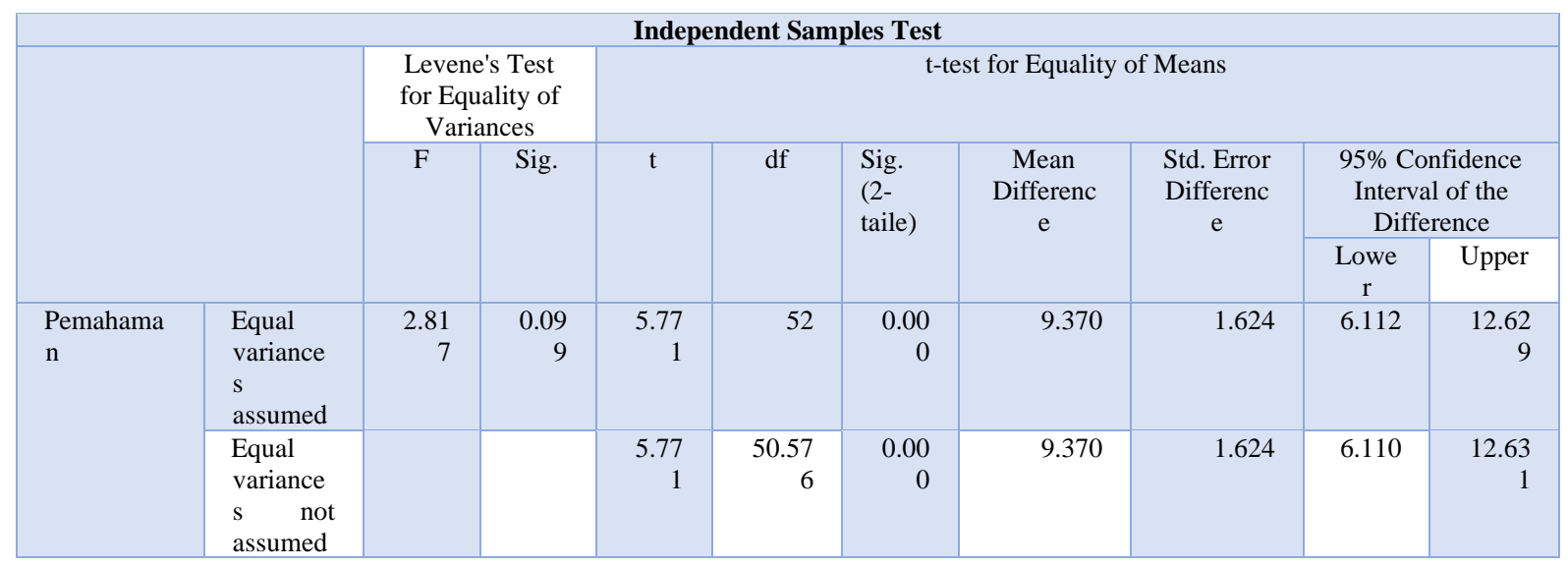

Berdasarkan data tabel tersebut dapat dilihat pada baris Equal variances assumed nilai signifikansi yang diperoleh adalah 0.000 nilai tersebut lebih kecil dari 0.05 dengan kata lain disimpulkan bahwa lebih unggul kemampuan pemahaman matematik antara siswa yang diajar menggunakan media animasi kartun dan motivasi tinggi dengan siswa yang diajar dengan media gambar.

2. Lebih unggul kemampuan pemahaman matematik siswa yang belajar dengan media animasi kartun pada siswa yang memiliki motivasi sedang dengan siswa yang belajar dengan media gambar yang memiliki motivasi sedang. 
Tabel 3. Rangkuman hasil Uji-t A1B2 dan A2B2

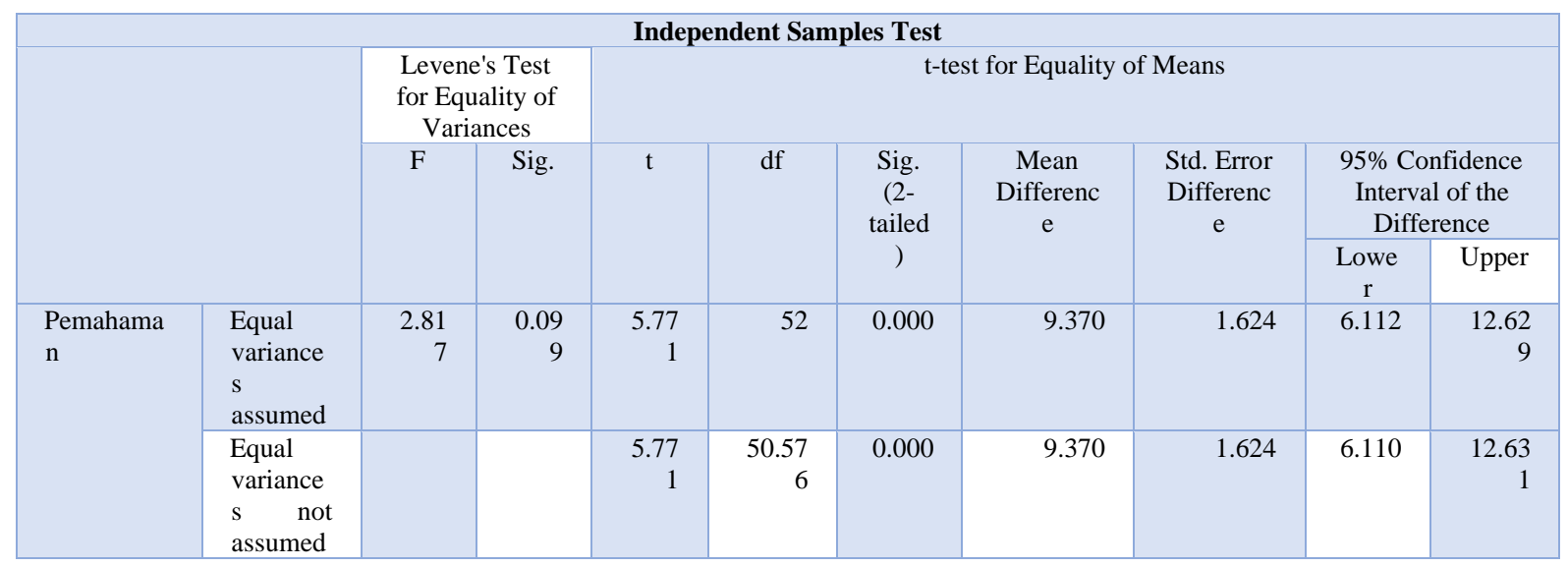

Berdasarkan tabel tersebut pada baris Equal variances assumed nilai signifikansi yang dipeoleh adalah 0,000 nilai tersebut lebih kecil dari 0,05 dengan kata lain disimpulkan bahwa lebih unggul kemampuan pemahaman matematik antara siswa yang belajar dengan menggunakan media animasi kartun dan motivasi sedang dengan siswa yang belajar dengan menggunakan media gambar dan motivasi sedang.

3. Lebih unggul kemampuan pemahaman matematik siswa yang belajar dengan media animasi kartun pada siswa yang memiliki motivasi rendah dengan siswa yang belajar dengan media gambar yang memiliki motivasi rendah.

Tabel 4 Rangkuman hasil Uji-t A1B3 dan A2B3

\begin{tabular}{|c|c|c|c|c|c|c|c|c|c|c|}
\hline \multicolumn{11}{|c|}{ Independent Samples Test } \\
\hline & & \multicolumn{2}{|c|}{$\begin{array}{l}\text { Levene's Test } \\
\text { for Equality of } \\
\text { Variances }\end{array}$} & \multicolumn{7}{|c|}{ t-test for Equality of Means } \\
\hline & & \multirow[t]{2}{*}{$\mathrm{F}$} & \multirow[t]{2}{*}{ Sig. } & \multirow[t]{2}{*}{$\mathrm{t}$} & \multirow[t]{2}{*}{ df } & \multirow{2}{*}{$\begin{array}{l}\text { Sig. } \\
(2- \\
\text { tailed } \\
\quad)\end{array}$} & \multirow[t]{2}{*}{$\begin{array}{c}\text { Mean } \\
\text { Differenc } \\
\text { e }\end{array}$} & \multirow[t]{2}{*}{$\begin{array}{c}\text { Std. Error } \\
\text { Differenc } \\
\text { e }\end{array}$} & \multicolumn{2}{|c|}{$\begin{array}{l}\text { 95\% Confidence } \\
\text { Interval of the } \\
\text { Difference }\end{array}$} \\
\hline & & & & & & & & & $\begin{array}{c}\text { Lowe } \\
r\end{array}$ & Upper \\
\hline \multirow[t]{2}{*}{$\begin{array}{l}\text { Pemahama } \\
\mathrm{n}\end{array}$} & $\begin{array}{l}\text { Equal } \\
\text { variance } \\
\text { s } \\
\text { assumed }\end{array}$ & $\begin{array}{r}2.81 \\
7\end{array}$ & $\begin{array}{r}0.09 \\
9\end{array}$ & $\begin{array}{r}5.77 \\
1\end{array}$ & 52 & 0.000 & 9.370 & 1.624 & 6.112 & $\begin{array}{r}12.62 \\
9\end{array}$ \\
\hline & $\begin{array}{l}\text { Equal } \\
\text { variance } \\
\mathrm{s} \text { not } \\
\text { assumed }\end{array}$ & & & $\begin{array}{r}5.77 \\
1\end{array}$ & $\begin{array}{r}50.57 \\
6\end{array}$ & 0.000 & 9.370 & 1.624 & 6.110 & $\begin{array}{r}12.63 \\
1\end{array}$ \\
\hline
\end{tabular}

Berdasarkan tabel tersebut pada baris Equal variances assumed nilai signifikansi yang diperoleh adalah 0.000 nilai tersebut lebih kecil dari 0.05 dengan kata lain dapat disimpulkan bahwa lebih unggul kemampuan pemahaman matematik antara siswa yang belajar dengan media animasi kartun dan motivasi rendah dengan siswa yang belajar dengan media gambar dan motivasi rendah. Anava dua jalur, uji hipotesis ini dilakukan untuk mengetahui pengaruh interaksi pembelajaran matematika dengan berbantuan media animasi kartun dan motivasi belajar terhadap pemahaman matematik siswa. Untuk mencari pengaruh tersebut maka uji hipotesis yang dilakukan dengan menggunakan Teknik anava dua jalur. Hasil perhitungan menggunakan anava dua jalur sebagai berikut : 
Tabel 5. Rangkuman Analisis Varian Dua Jalur

\begin{tabular}{|c|c|c|c|c|c|}
\hline \multicolumn{6}{|c|}{ Tests of Between-Subjects Effects } \\
\hline Dependent Variable: & Pemahaman & & & & \\
\hline Source & $\begin{array}{c}\text { Type III Sum of } \\
\text { Squares }\end{array}$ & df & Mean Square & $\mathrm{F}$ & Sig. \\
\hline Corrected Model & $2150.480^{a}$ & 5 & 430.096 & 23.311 & 0.000 \\
\hline Intercept & 243621.231 & 1 & 243621.231 & 13204.216 & 0.000 \\
\hline Kelas & 1310.539 & 1 & 1310.539 & 71.031 & 0.000 \\
\hline Motivasi & 783.746 & 2 & 391.873 & 21.239 & 0.000 \\
\hline Kelas * Motivasi & 128.164 & 2 & 64.082 & 3.473 & 0.039 \\
\hline Error & 885.613 & 48 & 18.450 & & \\
\hline Total & 266657.000 & 54 & & & \\
\hline Corrected Total & 3036.093 & 53 & & & \\
\hline
\end{tabular}

Berdasarkan hasil analisi Anava dua jalur dengan taraf signifikan 0.05 diperoleh :

a. Berdasarkan hasil Anava dua jalur pada baris kelas diperoleh nilai signifikasi sebesar $0.000<0.05$ berarti lebih unggul signifikan antara kelas eksperimen dengan media animasi kartun dan kelas kontrol dengan media gambar. Dengan kata lain lebih unggul kemampuan pemahaman matematik siswa yang belajar dengan menggunakan media animasi kartun dari pada siswa yang belajar dengan menggunakan media gambar.

b. Pada baris motivasi diperoleh nilai signifikasi sebesar $0.000<0.05$, artinya lebih unggul kemampuan pemahaman matematik berdasarkan kategori motivasi belajar tinggi, sedang dan rendah.

c. Pada baris kelas*motivasi diperoleh nilai signifikasi sebesar 0.039 , secara statistik dapat dinyatakan terdapat pengaruh interaksi yang signifikan antara media belajar yang digunakan dan motivasi belajar terhadap kemampuan pemahaman matematik.

Sete lah diketahui adanya pengaruh interaksi yang signifikan, maka untuk mengetahui perbedaan rata-rata pada masing-masing kelompok sampel dilakukan uji lanjutan yaitu uji Teknik Tuckey sebagai berikut :

Tabel Rangkuman Hasil Uji Komparasi Rerata Antar Kolom pada masing-masing Kategori Motivasi Belajar

\begin{tabular}{|c|c|c|c|c|c|c|}
\hline \multicolumn{7}{|c|}{ Multiple Comparisons } \\
\hline \multicolumn{7}{|c|}{ Dependent Variable: Pemahaman } \\
\hline \multicolumn{7}{|c|}{ Tukey HSD } \\
\hline \multirow{2}{*}{ (I) } & \multirow{2}{*}{$\begin{array}{l}(\mathrm{J}) \\
\text { Motivasi }\end{array}$} & \multirow{2}{*}{$\begin{array}{l}\text { Mean Difference } \\
(\mathrm{I}-\mathrm{J})\end{array}$} & \multirow{2}{*}{$\begin{array}{l}\text { Std. } \\
\text { Error }\end{array}$} & \multirow[t]{2}{*}{ Sig. } & \multicolumn{2}{|c|}{ 95\% Confidence Interval } \\
\hline & & & & & Lower Bound & Upper Bound \\
\hline \multirow[t]{2}{*}{ Tinggi } & Sedang & $6.32^{*}$ & 1.469 & 0.000 & 2.77 & 9.88 \\
\hline & Rendah & $10.55^{*}$ & 1.604 & 0.000 & 6.67 & 14.43 \\
\hline \multirow[t]{2}{*}{ Sedang } & Tinggi & $-6.32^{*}$ & 1.469 & 0.000 & -9.88 & -2.77 \\
\hline & Rendah & $4.23^{*}$ & 1.375 & 0.010 & 0.90 & 7.55 \\
\hline \multirow[t]{2}{*}{ Rendah } & Tinggi & $-10.55^{*}$ & 1.604 & 0.000 & -14.43 & -6.67 \\
\hline & Sedang & $-4.23^{*}$ & 1.375 & 0.010 & -7.55 & -.90 \\
\hline \multicolumn{7}{|c|}{$\begin{array}{l}\text { Based on observed means. } \\
\text { The error term is Mean Square }(\text { Error })=18.450 \text {. }\end{array}$} \\
\hline
\end{tabular}

Berdasarkan uji komparasi antar kolom, dengan taraf signifikasi 0.05 diperoleh bahwa:

a. Motivasi tinggi (I) dan sedang (J) diperoleh nilai signifikasi sebesar 0.000 artinya tidak terdapat perbedaan yang signifikan namun jika dilihat dari selisih reratanya yaitu sebasar 6.32 dan merupakan bilangan positif maka dapat dinyatakan bahwa 
kemampuan pemahaman matematik siswa dengan motivasi tinggi lebih baik daripada siswa dengan motivasi sedang.

b. Motivasi tinggi (I) dan rendah (J) diperoleh nilai signifikasi sebesar 0.000 artinya lebih unggul signifikan, dan berdasarkan selisih reratanya yaitu 10.55 maka dapat disimpulkan bahwa kemampuan pemahaman matematik siswa motivasi tinggi lebih baik daripada siswa dengan motivasi rendah.

c. Motivasi rendah (I) dan sedang (J) diperoleh nilai signifikasi sebesar 0.010, artinya tidak terdapat perbedaan yang signifikan namun berdasarkan selisih reratanya yaitu 4.23 dan merupakan bilangan positif maka dapat dinyatakan bahwa kemampuan pemahaman matematik yang memiliki motivasi sedang lebih baik dari pada siswa yang memiliki motivasi rendah.

Berdasarkan pengujian hipotesis dan hasil penelitian, maka dideskripsikan pembahasan dari ketiga hipotesis penelitian sebagai berikut:

\section{Hipotesis Pertama}

Hasil analisis statatistik melalui uji perbedaan rata-rata (uji-t) diperoleh nilai signifikansi sebesar $0.000<0.05$ dan hasil uji anova dua jalan dengan nilai signifikansi sebesar $0.039<$ 0.05. dari kedua hasil uji hipotesis tersebut dapat disimpulkan bahwa lebih unggul kemampuan pemahaman matematik siswa antara siswa yang pembelajaran media animasi kartun dan media gambar.

Karsidi (2018) Menyatakan media animasi merupakan media pembelajaran yang berbasis audiovisual karena media ini manyajikan informasi berupa sesuatu yang dapat dilihat dan didengar bersamaan. Media pembelajaran berbasis audiovisual ini dapat menyajikan materi pembelajaran yang lebih menarik, tidak membosankan dan mempermudah penyampaian materi. Kriteria pemilihan animasi kartun sebagai media pembelajaran, sebagai berikut:

a) Animasi kartun yang digunakan mempunyai hubungan pengalaman dan lingkungan hidup dengan siswa;

b) Animasi kartun harus sesuai dengan siswa, diperbolehkan bahan kartun yang menarik motivasi siswa dan disesuaikan dengan kemampuan bahasa serta kecerdasan siswa;

c) Animasi kartun yang memiliki dialog yang sesuai dengan usia siswa;

d) Animasi kartun yang dipilih sesuai dengan materi pembelajaran;

e) Animasi kartun yang dipilih tidak menyangkut unsur SARA;

f) Animasi kartun yang dipilih sesuai dengan kebijakan guru yang disesuaikan dengan tahapan belajar siswa.

Animasi kartun menarik untuk digunakan dalam proses pembelajaran, animasi digunakan agar motivasi belajar siswa meningkat dan tentunya akan mempengaruhi pemahaman matematik pada materi yang diberikan dan hasil belajar pun akan lebih maksimal, pemahaman matematik akan tercapai karena pembelajaran matematika diperlukan media sebagai perantara karena materi matematika akan mudah dipahami apabila menggunakan media terutama media audio visual yang melibatkan indra pendengaran dan indra penglihatan dan yang terutama media yang digunakan harus menarik. Berdasarkan uraian diatas dapat disimpulkan bahwa media animasi kartun dapat meningkatkan kemampuan pemahaman matematik siswa.

\section{Hipotesis Kedua}

Lebih unggul kemampuan pemahaman matematik antara siswa yang memiliki motivasi tinggi, sedang dan rendah pada peserta didik yang diajar meenggunakan media animasi kartun dengan siswa yang di ajar menggunakan media gambar. Hasil pengujian hipotesis melalui uji-t menyatakan nilai signifikasni untuk masing-masing pengujian yaitu $0.000,0.000,0.000$ nilai- 
nilai tersebut lebih kecil dari 0.05 artinya lebih unggul kemampuan pemahaman matematik berdasarkan kategori motivasi.

Kompri (2016) mengatakan motivasi adalah suatu perubahan energi di dalam diri pribadi seseorang yang ditandai dengan timbulnya afektif (perasaan) dan reaksi untuk mencapai tujuan. Keberhasilan belajar siswa dalam proses pembelajaran dipengaruhi oleh motivasi yang ada didalam dirinya. Aspek yang mempengaruhi proses pembelajaran salah satunya adalah adanya motivasi yang tinggi dari para siswa. Siswa yang memiliki motivasi belajar yang tinggi terhadap pembelajaran maka mereka akan berusaha untuk memiliki keinginan melakukan sesuatu yang dapat memperoleh hasil atau tujuan tertentu.

Kompri (2016) mengatakan bahwa dalam proses pembelajaran motivasi baik bagi guru dan siswa adalah sangat penting dalam mencapai keberhasilan belajar sesuai tujuan yang diharapkan. Menurut Pratiwi, Wahyuningrum dan Adji (2019) menyarankan guru hendaknya dapat memberikan motivasi dan pendampingan terhadap siswa yang memiliki tingkat kecemasan matematika sedang dan tinggi, karena siswa cenderung memiliki perasaan takut terhadap matematika yang dapat mempengaruhi kemampuian berpikirnya. Berdasarkan uraian di atas dapat disimpulkan bahwa siswa yang memiliki motivasi yang tinggi dalam belajar akan melakukan kegiatan belajar dengan baik sehingga tujuan dari proses pembelajaran yang sudah ditetapkan dapat dicapai.

\section{Hipotesi Ketiga}

Terdapat pengaruh interaksi antara media pembelajaran dan motivasi belajar tehadap kemampuan pemahaman matematik. Hal tersebut dinyatakan berdasarkan hasi ANAVA dua jalur dengan perolehan nilai signifikansi sebesar $0.000<0.05$. Pemahaman matematik merupakan hal yang penting dalam pembelajaran matematika. Fungsi pengajaran matematika diantaranya adalah memahami konsep-konsep matematika dan saling keterkaitannya dan penerapannya untuk menyelesaikan masalah dalam kehidupan sehari-hari dan teknologi, membentuk sikap positif terhadap pembelajaran matematika, yaitu merasa tertarik untuk mempelajari matematika.

Matematika berhubungan erat dengan konsep, sehingga apabila ingin sukses pada bidang matematika harus menguasai konsep matematika terlebih dahulu. Konsep merupakan kategori atau kesamaan karakteristik untuk mengomunikasikan pengetahuan, dengan pemahaman konsep dapat memungkinkan untuk memperoleh pengetahuan yang tak terbatas (Winata \& Friantini, 2020).

Dalam matematika, setiap konsep saling berkaitan dan menjadi prasyarat bagi konsep yang lainnya. Konsep matematika saling berkaitan satu dan lainnya maka untuk mempelajarinya harus runtut dan berkesinambungan dan apabila konsep dapat dipahami maka akan memudahkan untuk memahami konsep berikutnya yang lebih kompleks (Hidayat, 2018). Oleh karena itu pemahaman konsep menjadi penting bagi pemahaman matematika apalagi konsep dasar. Konsep dasar pembelajaran matematika berupa materi yang baru diajarkan dan ditanamkan, kemudian menjadi prasyarat untuk memahami konsep selanjutnya (Karso, 2014).

Pemahaman konsep merupakan kemampuan anak untuk menuangkan ide yang dimilikinya dalam bentuk abstrak ke konkret sehingga dapat dengan mudah dipahami orang lain (Ardiansyah, 2018) Berdasarkan uraian dapat disimpulkan bahwa terdapat pengaruh interaksi antara media animasi kartun dan motivasi belajar terhadap kemampuan pemahaman matematik. 


\section{KESIMPULAN}

Berdasarkan hasil penelitian dan pembahasan maka kesimpulan penelitian sebagai berikut:

1. Lebih unggul kemampuan pemahaman matematik siswa yang diajar dengan menggunakan media animasi dengan siswa yang diajar dengan menggunakan media gambar.

2. Lebih unggul kemampuan pemahaman matematik antara siswa yang memiliki motivasi tinggi, sedang dan rendah pada siswa yang diajar dengan meenggunakan media animasi kartun

3. Terdapat pengaruh interaksi antara penggunaan media animasi dan motivasi belajar terhadap kemampuan pemahaman matematik

Berdasarkan kesimpulan hasil penelittian, dapat dikemukakan beberapa saran sebagai upaya mengoptimalkan kemampuan pemahaamn matematik sebagai berikut:

1. Bagi Siswa

Siswa diharapkan terlibat aktif dalam mengikuti pembelajaran di kelas sehingga dapat memahami materi yang diajarakan dan memperoleh hasil belajar yang optimal.

2. Bagi Guru

Guru diharapkan memperhatikan motivasi belajar siswa agar mampu memilih metode dan media belajar yang tepat dalam merancang pembelajaran sehingga mampu meningkatkan kemampuan pemahaman matematik siswa.

3. Bagi Peneliti Lain

Penelitian selanjutnya diharapkan mampu memperdalam dan memperluas lingkup penelitian sehingga memberikan dampak yang lebih besar

\section{DAFTAR PUSTAKA}

Ardiansyah, A. (2018). Pemahaman Konsep Matematika Ditinjau Dari Efikasi Diri dan Kemandirian Belajar. Alfarisi: Jurnal Pendidikan MIPA, 1 (1)

Fraenkel, Jack R \& Norman E. Wallen(2009). How to Design and Evaluate Research in Education. New York: McGraw-Hill.

Hadi, Syamsul \& Novaliyosi (2019). Prosiding Seminar Nasional \& Call For Papers Program Studi Magister Pendidikan Matematika Universitas Siliwangi Tasikmalaya, 19 Januari 2019 ISBN: 978-602-9250-39-8

Hasanah, U., \& Nulhakim, L. (2015). Pengembangan Media Pembelajaran Film Animasi Sebagai Media Pembelajaran Konsep Fotosintesis. Jurnal Penelitian Dan Pembelajaran IPA, 1(1), 91.

Hidayat, P. W. (2018). Analisis Profil Minat Belajar dan Kemampuan Pemahaman Konsep Dasar Matematika SD Pada Mahasiswa S1 PGSD STKIP Muhammadiyah Muara Bungo. Lemma, 4 (1)

Kamarullah. (2017). Pendidikan Matematika Di sekolah Kita. Jurnal Pendidikan dan Pembelajaran Matematika, 22.

Kompri.(2016). Motivasi Pembelajaran Perspektif Guru dan Siswa. Bandung : PT Rosda Karya.

Nizam. 2016. Ringkasan Hasil-hasil Asesmen Belajar Dari Hasil UN, PISA, TIMSS, INAP. Puspendik 
Pratiwi, D.Wahyuningrum, E. Adji, S.S.(2019). Profil Kemampuan Berpikir Kreatif Siswa Sekolah Menengah Pertama Ditinjau dari Tingkat Kecemasan Matematika dan Jender. Jurnal Pendidikan, Volume 20, Nomor 1.

Ravik.Karsidi (2018). Media Pembelajaran Inovatif dan Pengembangannya. Bandung : PT Remaja Rosdakarya Offset.

Sanjaya, Wina. (2010). Kurikulum dan pembelajaran, Teori dan praktek Pengembangan Kurikulum KTSP. Jakarta : Kencana.

Supriadi.(2016).Kreativitas guru dan siswa melalui pembelajaran etnomatematika Sunda. In Seminar Nasional Pendidikan Dasar UPI Kampus Serang. Serang, 14 Mei 2016

Zainal Arifin, Penelitian Pendidikan Dan Metode Paradigma Baru (Bandung : Remaja Rosdakarya, 2011), h 85

Zainal Arifin Evaluasi pembelajaran. (Cet ke V ; Bandung : PT Remaja Rosdakarya, 2013), h.153

Zakirman, Z., \& Hidayati, H. (2017). Praktikalitas Media Video dan Animasi dalam Pembelajaran Fisika di SMP. Jurnal Ilmiah Pendidikan Fisika Al- Biruni, 6(1), 85-93. 